Article

\title{
Lethal and Sublethal Effects of Three Microbial Biocontrol Agents on Spodoptera litura and Its Natural Predator Rhynocoris kumarii
}

\author{
Kitherian Sahayaraj 1,*(D), Natarajan Subash ${ }^{1}$, Robert W. Allingham ${ }^{2}$, Vivek Kumar ${ }^{3,4}$ (ID), \\ Pasco B. Avery ${ }^{5}$ (D), Lucky K. Mehra ${ }^{6}$ (D), Cindy L. McKenzie ${ }^{4}$ and Lance S. Osborne ${ }^{3}$ \\ 1 Crop Protection Research Centre, St. Xavier's College (Autonomous), Manonmaniam Sundaranar \\ University, Palayamkottai 627002, India; nsubash@gmail.com \\ 2 Fruinlaan 43, 5624 DA Eindhoven, the Netherlands; allingham.rob@gmail.com \\ 3 Mid-Florida Research and Education Center, Institute of Food and Agricultural Sciences, \\ University of Florida, 2725, South Binion Road, Apopka, FL 32703, USA; vivekiari@ufl.edu (V.K.); \\ lsosborn@ufl.edu (L.S.O.) \\ 4 United States Department of Agriculture, Agricultural Research Services, 2001 South Rock Road, \\ Fort Pierce, FL 34945, USA; cindy.mckenzie@ars.usda.gov \\ 5 Indian River Research and Education Center, Institute of Food and Agricultural Sciences, \\ University of Florida, 2199 South Rock Road, Fort Pierce, FL 34945, USA; pbavery@ufl.edu \\ 6 Department of Plant Pathology, Kansas State University, 1712 Claflin Rd., 4024 Throckmorton Center, \\ Manhattan, KS 66506, USA; luckymehra@ksu.edu \\ * Correspondence: ksraj48@gmail.com; Tel.: +91-046-2426-4376
}

Received: 16 June 2018; Accepted: 9 August 2018; Published: 14 August 2018

\begin{abstract}
Entomopathogenic microbes such as Spodoptera litura nucleopolyhedrovirus (SpltNPV), Metarhizium anisopliae, and Pseudomonas fluorescens are biological agents used for the control of multiple arthropod pests. The objective of this study was to assess their effects on the biological parameters of Spodoptera litura (Lepidoptera: Noctuidae) larvae, and its natural reduviid predator Rhynocoris kumarii (Hemiptera: Reduviidae) under laboratory conditions. Results suggested that P. fluorescens reduced the food consumption index, relative growth rate, approximate digestibility, the efficiency of conversion of ingested food, and the efficiency of conversion of digested food of S. litura third instar larvae compared to prey infected with M. anisopliae and SpltNPV. Both SpltNPV and M. anisopliae caused similar mortality of S. litura life stages after $96 \mathrm{~h}$ of observation. To observe the effect of an infected prey diet on predator behavior, infected $S$. litura larvae were offered to the third, fourth, and fifth instar nymphs of R. kumarii, and their prey handling time, predation rate (number/day/predator), developmental period, and the survival rate was recorded. When the life stages of R. kumarii were offered entomopathogen-infected S. litura larvae, their predation rate was comparable to or higher than the untreated control. The juvenile predator, after feeding on P. fluorescens-infected S. litura larvae, had a significantly longer developmental period (2-4 days) compared to those fed on larvae infected with other microbial control agents. However, feeding on $P$. fluorescens alone did not affect the predator nymphal survival rate or the adult sex ratio. Although three entomopathogens had some degree of effect on the biological parameters of R. kumarii, the outcome of this study suggests that integration of reduviids with the tested entomopathogens are a compatible and potentially effective strategy for the management of S. litura populations. However promising, this combined strategy needs to be tested under field conditions to confirm the laboratory findings.
\end{abstract}

Keywords: Metarizhium anisopliae; Pseudomonas fluorescens; integrated pest management; field crop pest; nucleopolyhedrovirus; entomopathogens 


\section{Introduction}

The cutworm, Spodoptera litura (Fab.) (Lepidoptera: Noctuidae), known to attack over 120 plant species among vegetables, fruits, and ornamentals worldwide, is a serious pest of field crops in India [1]. It is widespread throughout Indian states and known for its economic impact in cotton, tobacco, and soybean production [2], and in groundnut, it is known to cause yield losses of 35-55\% [3]. Due to the economic importance of many of its plant hosts, insecticide applications are considered the primary method for managing S. litura during the crop growing seasons [3].The indiscriminate and large-scale use of synthetic chemical pesticides to manage this pest has resulted in ecological imbalances, especially among natural enemies, as well as toxic effects on other living organisms, including humans [4]. There are also reports that $S$. litura has developed resistance against many synthetic insecticides [5-7], which may have direct consequences on the agricultural sectors in the developing nations with limited resources. Thus, in order to offer our growers alternatives to harmful synthetic chemical pesticides, it is imperative to explore eco-friendly (ecological + economical) pest management strategies utilizing biological control agents that could provide similar efficacy against this pest.

In the past, several researchers endorsed the utility of naturally occurring entomopathogens such as Spodoptera litura nucleopolyhedrovirus (SpltNPV), Metarizhium anisopliae (Metsch.) Sorokin (=flavoviride) Gams and Rozsypal var. acridum, and Pseudomonas fluorescens (Trevisan) Migula [8-14] for management of field crop pests. In India, under field conditions, nuclear polyhedrosis virus (NPV-S) reduced S. litura populations in cabbage [15] and soybean [16]. In Assam, following the application of M. anisopliae (strains MTCC-4034 and 4645), termite populations were reduced and tea leaf yield was improved [17]. There is abundant literature available for the utilization of SpltNPV and M. anisopliae [17-26], but very little published information concerning the efficacy of using $P$. fluorescens against field crop pests. This pseudomonas bacteria were shown to be effective against certain arthropod pests [27], including tobacco hornworm, Manduca sexta L. [12], and the spider mites Oligonychus coffeae Nietner and O. afrasiaticus Mc Gregor [28,29].

Hunter reduviids (Reduviidae) are generalist predators of multiple species of Lepidoptera, Coleoptera, Hemiptera, Orthoptera, and Isoptera [30]. These predators are commonly found in the field of many agronomic crops, and they play a major role in the natural suppression of several pests including Helicoverpa armigera Hubner, Creontiades dilutus (Stål), Spodoptera litura (Fab.), Dysdercus cingulatus (Fab.), Phenacoccus solenopsis (Tinsley), Aphis gossypii (Glover), Euproctis mollifera (Thumberg), and Anomis flava (Fabricius) [31-35]. In India, among several reduviid species, Rhynocoris kumarii Ambrose and Livingstone has been reported to feed on economically important agricultural arthropod pests under controlled and field conditions [34-41]. In cotton agroecosystems, augmentative releases of this predator have been recommended for the management of S. litura, H. armigera, and E. mollifera $[37,40]$, whereas in okra, the reduviids have been found effective against $H$. armigera and A. flava [38].

Authors have explored the multitrophic interactions and studied the effects of entomopathogenic microbes against nontarget organisms including natural enemies $[42,43]$. However, the interaction of such microbial biopesticides with the predatory reduviids, such as $R$. kumarii, is still understudied. Sajap et al. [44] evaluated the impact of nuclear polyhedrosis virus (NPV) on the hemipteran predator, Sycanus leucomesus Walker, under laboratory conditions and found that the NPV treatment reduced nymphal survival rate, adult longevity, and fecundity. Similarly, Abbas et al. [45] assessed the impact of NPV-infected Anticarsia gemmatalis (Hübner) against the predatory stinkbug, Podisus maculiventris (Say), and found that they were compatible when applied in combination. In India, the majority of research has focused on assessing the impact of synthetic broad-spectrum insecticides against R. kumarii [46], and the side-effects of microbes and insecticides on other reduviid predators [47-50]. Due to the lack of information on the interaction of potential compatibility between microbial biocontrol agents of S. litura and their reduviid predators, their possible integration in various pest management programs has not been implemented. Thus, in this study, we determined the effect of the microbial biological 
control agents SpltNPV, M. anisopliae, and P. fluorescens on biological parameters including feeding time, number and amount of food consumed, nymphal development, and survival of R. kumarii when exposed to infected $S$. litura larvae.

\section{Materials and Methods}

\subsection{Collection and Rearing of Insects}

Life stages of $R$. kumarii were collected from the scrub jungles which bordered the cotton agroecosystems of the Marunthuvazh Malai $\left(8.1323^{\circ} \mathrm{N}, 77.5118^{\circ} \mathrm{E}\right)$, Kanyakumari district, Tamil $\mathrm{Nadu}$, India, and were maintained under laboratory conditions at $30 \pm 1{ }^{\circ} \mathrm{C}$ and $60-70 \%$ relative humidity $(\mathrm{RH})$ under a $11 \mathrm{~h}$ light (L): $13 \mathrm{~h}$ dark (D) photoperiod for three generations. They were reared on third, fourth, and fifth stadium larvae of $S$. litura, and were kept in round plastic boxes $(6.5 \mathrm{~cm} \times 16.0 \mathrm{~cm}$; Sun Shine, Tirunelveli, India). Filter paper was placed at the bottom of the box, and chart paper folded into a zigzag pattern $(10 \times 15 \mathrm{~cm})$ was placed on top of it for nesting of the predator. Newly hatched nymphs $(\geq 24 \mathrm{~h}$ ) were used for experimental purposes.

Life stages of $S$. litura were collected from groundnut, castor, and okra fields in the Tirunelveli district, Tamil Nadu, India. The larvae were reared in the laboratory in plastic containers (2 L capacity, $20 \mathrm{~cm}$ diameter) on fresh castor bean leaves. The castor plants were grown in the crop screen house. Newly emerged third instar larvae ( $>6 \mathrm{~h}$ ) weighing $0.3-0.35 \mathrm{~g}$ were used for the experiments to avoid any ambiguity due to biomass. Cotton (variety SVPR2) plants were seeded in plastic trays in a screen house under natural lighting conditions (30 $\pm 2{ }^{\circ} \mathrm{C} ; 55-67 \% \mathrm{RH} ; 11: 13 \mathrm{~h}$ L:D photoperiod). One week after germination, the cotton seedlings were individually transplanted into $1 \mathrm{~L}$ mud pots. The seedlings were fertilized with NPK fertilizer (80:40:40 of N, $\mathrm{P}_{2} \mathrm{O}_{5}, \mathrm{~K}_{2} \mathrm{O}$ ) weekly (5-10 g/pot) and watered as needed. Four-week old cotton plants were used in all experiments. The experimental setup was maintained under laboratory conditions as described above.

\subsection{Microbial Biocontrol Agents and Bioassay for Assessment}

Stock culture of $M$. anisopliae $\left(1.2 \times 10^{11}\right.$ conidia $\left./ \mathrm{mL}\right)$ was provided by the Crop Protection Research Centre, and both SpltNPV $\left(1 \times 10^{8}\right.$ polyhedral occlusion bodies $)$ and P. fluorescens $(1 \mathrm{~mL}$ of the broth $=2 \times 10^{8}$ colony-forming units/gram) were purchased from the district agricultural office in Palayamkottai as a technical formulated liquid. Viability for all the microbial formulations was $>95 \%$. The microbial product suspensions were sprayed with a hand sprayer (Shradha Plastic, Mumbai, India) on both sides of the cotton (variety SVPR2) leaf surfaces on the plants until runoff. The treated leaves were left to air-dry naturally in the laboratory. Leaves sprayed with sterilized tap water were used as a control treatment. Treated leaves were fed to third instar S. litura larvae as needed. They were kept in plastic containers $(6.5 \mathrm{~cm}$ diameter and $9 \mathrm{~cm}$ height) and covered with muslin cloth (Ram Textiles, Erode, Tamil Nadu, India). The larvae were allowed to feed on cotton leaves for $96 \mathrm{~h}$ continuously under the laboratory conditions described above. Mortality was recorded 48, 72, and $96 \mathrm{~h}$ after treatment. There were 10 replicate leaves per treatment and untreated controls were used for each treatment.

\subsection{Determining the Feeding Deterrence Index}

Feeding deterrence index (FDI) was determined using a leaf disk no-choice assay. Disks $\left(8 \mathrm{~cm}^{2}\right.$; mean fresh weight $=300-320 \mathrm{mg}$ ) were cut from cotton leaves and dipped to insure coverage on both sides for each of the following treatments: (1) $5.0 \mathrm{~mL}$ of the $M$. anisopliae suspension, which was emulsified with Tween $80^{\circledR}(0.1 \%)$ solution as a carrier, (2) technical grade liquid formulation of SpltNPV, and (3) technical grade liquid formulation of $P$. fluorescens. The products used for the treatments of SpltNPV and P. fluorescens were used without an adjuvant because there was a carrier present in the formulation. Control cotton leaves were dipped in $5.0 \mathrm{~mL}$ water $(99 \mathrm{~mL}$ distilled water $+1 \mathrm{~mL}$ Tween $80^{\circledR}(0.1 \%)$ solution. The leaf disks were dried at room temperature, and newly 
emerged third instar S. litura larvae were removed from the stock culture and starved for $4 \mathrm{~h}$ before testing. These preweighed (in $\mathrm{mg}$ ) larvae were placed into Petri dishes $(9.5 \mathrm{~cm} \times 1.5 \mathrm{~cm})$ containing either a microbial treatment or surfactant $\left(0.1 \%\right.$ Tween $\left.80^{\circledR}\right)$ solution on a pretreated cotton leaf disk. Sterilized tap water and a small piece of moistened cotton was placed inside the Petri dishes to protect the leaves from desiccation. Ten replicate dish chambers (closed with lid) containing the leaf disk and the larva were used to assess the FDI values for each microbial treatment and control. Larvae were allowed to feed continuously for four days. Daily, the amount of food consumed by a larva was determined by weighing the disk using a mono-pan balance ( $0.1 \mathrm{mg}$ accuracy) (Dhona Instruments (P) Ltd., Kolkata, India). The percent FDI values were calculated using the following formula [50]:

$$
\mathrm{FDI}=(\mathrm{C}-\mathrm{T}) /(\mathrm{C}+\mathrm{T}) \times 100
$$

where $\mathrm{C}=$ the consumption of control disks $(\mathrm{mg})$ and $\mathrm{T}=$ the consumption of treated disks $(\mathrm{mg})$.

\subsection{Food Consumption}

Consumption of the cotton leaves was determined using third instar larvae of S. litura. Five larvae were maintained individually as mentioned above and fed ad libitum with cotton leaves. To avoid inconsistencies due to moisture loss, the weight of food consumed was determined by tracing the area consumed on filter paper as a function of the initial area before feeding. Food consumption was taken as the dry mass of initial leaf minus the final mass leftover. However, due to reports disputing the fresh weight of food reported by Waldbauer [51], the dry weight of the cultivars was determined by their characteristic moisture contents, which were between 85 and $89 \%$. Therefore, the fresh weight of insects was corrected to the dry weight by comparison with groups of insects reared under the same conditions as control insects and then air-dried at $100{ }^{\circ} \mathrm{C}$. The live body weight of each larva was recorded daily using a mono-pan balance for five consecutive days. Dry frass was collected daily and weighed. Six to eight replications were used for each treatment. The consumption, digestion, and utilization of treated cotton leaves by the third instar S. litura larvae were calculated using the following formulae:

$$
\begin{gathered}
\text { Food consumption index }(\mathrm{FCI})=\mathrm{E} / \mathrm{TA} \\
\text { Relative growth rate }(\mathrm{RGR})=\mathrm{P} / \mathrm{TA} \\
\text { Approximate digestibility }(\mathrm{AD})=100(\mathrm{E}-\mathrm{Fe}) / \mathrm{E} \\
\text { Efficiency of conversion of ingested food }(\mathrm{ECIF})=100(\mathrm{P} / \mathrm{E}) \\
\text { Efficiency of conversion of digested food }(\mathrm{ECDF})=(100) \mathrm{P} /(\mathrm{E}-\mathrm{Fe})
\end{gathered}
$$

where $\mathrm{T}=$ duration of the experimental period, $\mathrm{A}=$ mean dry weight of the insect during $\mathrm{T}, \mathrm{E}=\mathrm{dry}$ weight of food eaten, $\mathrm{Fe}=$ dry weight of frass produced, and $\mathrm{P}=$ dry weight gain of the insect.

\subsection{Rearing of Larvae with Entomopathogenic Microbes}

Infected prey with entomopathogenic microbes were reared for the reduviid R. kumarii predator. Freshly molted third instar larvae of S. litura were starved for $12 \mathrm{~h}$ and then treated with either M. anisopliae, SpltNPV, or P. fluorescens on an artificial diet plug made as prepared by Gupta et al. [19]. Control larvae were fed a diet plug inoculated with distilled water. Ten larvae were reared in plastic vials (2.0 diameter and $4.5 \mathrm{~cm}$ height) containing $3 \mathrm{~g}$ of diet. Larvae that ate the entire diet within $24 \mathrm{~h}$ were transferred to a vial containing fresh uncontaminated diet and reared under laboratory conditions as described above. Larvae that did not consume the diet were discarded. A total of 500-600 larvae were reared for each treatment with different entomopathogenic microbes. Microbial infection in S. litura larvae were identified based on their sluggish behavior with low or no food consumption, and later with either the growth of white mycelia in the case of $M$. anisopliae, or white- to brown-colored conidia for P. fluorescens, or the appearance of polyhedra of SpltNPV on the larval epicuticle. 


\subsection{Effect of Entomopathogenic Microbes on the Developmental Biology of the Predator}

In order to record the effect of prey infected with entomopathogenic microbes on the developmental biology of R. kumarii, six pairs of newly emerged adults from nymphs were fed on healthy $S$. litura larvae throughout their lives, and then they were selected for use in this experiment on the basis of their adult weight (50-80 mg/food is needed). The reduviid adult pairs were kept in plastic containers $(6.5 \mathrm{~cm}$ diameter and $9 \mathrm{~cm}$ height $)$ and allowed to mate. From the offspring, cohorts of 100 reduviid first instar nymphs were reared on healthy larvae throughout their entire nymphal period, which served as the control. For the experimental treatments, 30 reduviid nymphs were provided with: (1) SpltNPV-infected prey, (2) P. fluorescens formulation-infected prey, or (3) M. anisopliae-infected prey. The R. kumarii were offered 6 microbial-infected third instar $S$. litura larvae per predator for each category separately.

The developmental period, mortality of each stadium, and survival rate of the nymphs were recorded. Sex ratio was calculated from the total male and female emerged adults. In another similar experiment to that described above, newly emerged fourth and fifth instar larvae and adult predators were starved for 24, 48, 72, and $96 \mathrm{~h}$ first, and then they were provided with infected or noninfected S. litura third and fourth instar larvae. The handling time (paralyzing and sucking acts), amount of food consumed (FCI), and predatory rate (number of prey killed by a predator in a day) were recorded [51]. Percent reduction in the number of emerged adults was calculated by using the following formula:

$$
\mathrm{E}=[\mathrm{AEC}-\mathrm{AEE} / \mathrm{AEC}] \times 100
$$

where $\mathrm{E}=$ adult emergence, $\mathrm{AEE}=$ adults developing from larvae fed on microbe-treated prey, and AEC $=$ number of adults developing from reduviids fed on untreated prey. Eight to ten replicates were used for each life stage of the predator $(8,9$, and 10 replicates for SpltNPV, M. anisopliae, and the control and P. fluorescens, respectively).

\subsection{Statistical Analysis}

Any correlation between the reduviid predator weight and amount of food consumed, food consumption and fecal pellet production, and handling time and predation rate for each microbial treatment per S. litura larva was determined separately and for each instar. Weight gain between the control and SpltNPV-, M. anisopliae-, and P. fluorescens-infected prey fed to R. kumarii was analyzed using an ANOVA and treatment means were compared using a Tukey's honest significant difference (HSD) test $(p<0.05)$. ANOVA and Tukey's HSD test $(p<0.05)$ were also used to compare the incubation period, hatching percentage, and nymphal survival of the control with that of SpltNPV-, M. anisopliae-, and $P$. fluorescens-treated prey separately. The amount consumed by the predator amongst the control and SpltNPV-, M. anisopliae-, and P. fluorescens-treated prey, as well as for the four and fifth nymphal instar and adult, was compared using an ANOVA, with treatment means separated using a Tukey HSD test $(p<0.05)$. All statistical analyses were performed using SPSS ${ }^{\circledR}$ Version 13.0 software for Windows (SPSS Inc., Chicago, IL, USA).

\section{Results}

\subsection{Food Deterrence Index}

Irrespective of the entomopathogenic microbe-infected larvae consumed by the reduviid, the FDI percentages for the predator gradually increased from 24 to $96 \mathrm{~h}$ in the choice assay (Figure 1). In the no-choice test, R. kumarii after feeding on SpltNPV-infected S. litura larvae were deterred the most from eating at $24(F=249.5 ; \mathrm{df}=1,18 ; p<0.05), 48(F=250.0 ; \mathrm{df}=1,18 ; p<0.05)$, and $72 \mathrm{~h}(F=247.0 ; \mathrm{df}=1$, $18 ; p<0.05)$ post-exposure compared to the other microbial treatments. Metarhizium anisopliae-infected larvae significantly $(F=248.2, \mathrm{df}=1,18 ; p<0.05)$ deterred the reduviid from feeding compared to the 
other microbial treatments at $96 \mathrm{~h}$. The least percent deterrence for the reduviid compared with the other microbial treatments occurred with larvae infected with P. fluorescens 48,72 , and $96 \mathrm{~h}$ post-feeding.

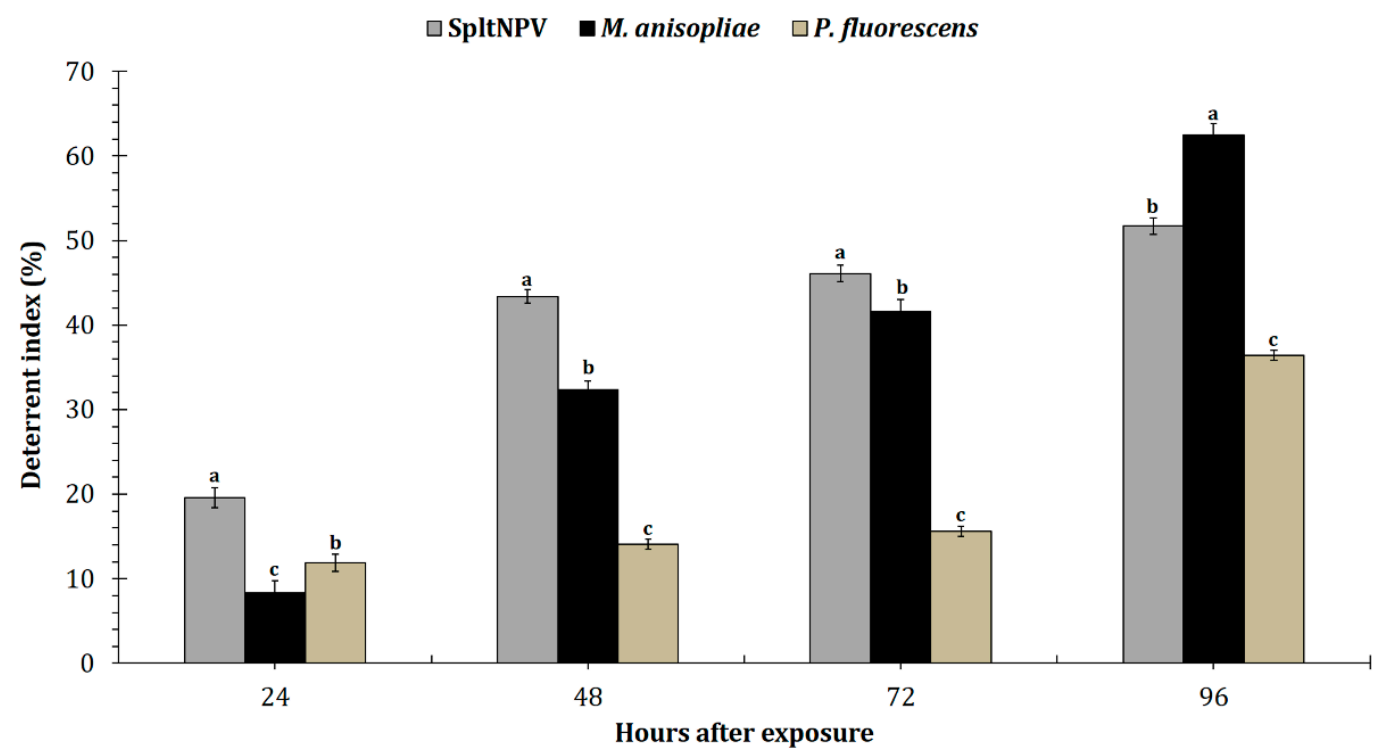

Figure 1. Effect of Spodoptera litura nucleopolyhedrovirus (SpltNPV)-, Metarhizium anisopliae-, and Pseudomonas fluorescens-infected S. litura larvae on the feeding deterrence of the reduviid as measured by the deterrent index (\%) during a non-choice test 24, 48, 72, and $96 \mathrm{~h}$ post-exposure; all deterrence index values are represented as means \pm SEM. Letters above the mean bars per treatment/exposure time that are different are significantly different (Tukey's test; $p<0.05$ ).

\subsection{Food Energy Budget}

The indices of food consumption, digestion, and utilization of treated cotton bean leaves by the third instar S. litura larvae are presented in Table 1.

Table 1. Different nutritional indices: food consumption index (FCI), relative growth rate (RGR), approximate digestibility (AD), efficiency of conversion of ingested food (ECIF), and the efficiency of conversion of digested food (ECDF) of the third instar S. litura larvae after exposure to cotton leaf disks. Larvae were treated with either Metarhizium anisopliae, Spodoptera litura nucleopolyhedrovirus (SpltNPV), or Pseudomonas fluorescens.

\begin{tabular}{cccccc}
\hline Treatments & FCI & RGR & AD & ECIF & ECDF \\
\hline SpltNPV & $28.2 \pm 2.7 \mathrm{~d}$ & $11.1 \pm 1.5 \mathrm{~d}$ & $52.1 \pm 2.0 \mathrm{~d}$ & $42.9 \pm 1.2 \mathrm{~d}$ & $40.1 \pm 2.5 \mathrm{~d}$ \\
M. anisopliae & $32.9 \pm 4.6 \mathrm{c}$ & $14.0 \pm 0.3 \mathrm{c}$ & $57.2 \pm 0.9 \mathrm{c}$ & $59.2 \pm 2.4 \mathrm{c}$ & $51.2 \pm 1.0 \mathrm{c}$ \\
P. fluorescens & $66.0 \pm 3.4 \mathrm{~b}$ & $17.9 \pm 0.1 \mathrm{~b}$ & $83.9 \pm 3.8 \mathrm{~b}$ & $65.7 \pm 1.5 \mathrm{~b}$ & $73.2 \pm 2.8 \mathrm{~b}$ \\
Control & $81.2 \pm 4.8 \mathrm{a}$ & $20.4 \pm 0.2 \mathrm{a}$ & $110.0 \pm 5.0 \mathrm{a}$ & $73.8 \pm 0.8 \mathrm{a}$ & $93.1 \pm 3.5 \mathrm{a}$ \\
\hline
\end{tabular}

Mean values ( \pm SEM) followed by different letters in a column are significantly different (Tukey's test, $p<0.05$ ).

The food consumption index (FCI: $F=4.17 ; \mathrm{df}=1,35 ; p<0.005$ ) and relative growth rate (RGR: $F=4.12 ; \mathrm{df}=1,35 ; p<0.005)$ of the third instar $S$. litura larvae were affected more by the SpltNPVtreated cotton leaves than either P. fluorescens or M. anisopliae. The values for the AD, ECIF, and ECDF indices were also significantly lower $(p<0.05)$ in the SpltNPV treatments compared to the other treatments. All of the microbial treatments had a similar effect on the S. litura larvae for the different nutritional indices which followed a general trend per treatment: control $>$ P. fluorescens $>M$. anisopliae $>$ SpltNPV. Food consumption by the $S$. litura larvae was positively correlated with the fecal pellet production in the control $\left(R^{2}=0.858\right), M$. anisopliae $\left(R^{2}=0.827\right)$, and P. fluorescens $\left(R^{2}=0.712\right)$ treatments; however, it showed a negative correlation for SpltNPV $\left(R^{2}=-0.951\right)$. 


\subsection{Larvicidal Activity of Entomopathogenic Microbes}

Among the three entomopathogenic microbial treatments, SpltNPV and M. anisopliae $(F=3.33$; $\mathrm{df}=2,29 ; p<0.005)$ caused a significantly higher corrected mortality of $S$. litura larvae than P. fluorescens (Figure 2). Mean S. litura mortality over time reported for the three treatments was $51.6 \pm 1.3$ for SpltNPV, followed by M. anisopliae (48.0 \pm 1.7$)$ and P. fluorescens (22.3 \pm 0.8$)$.

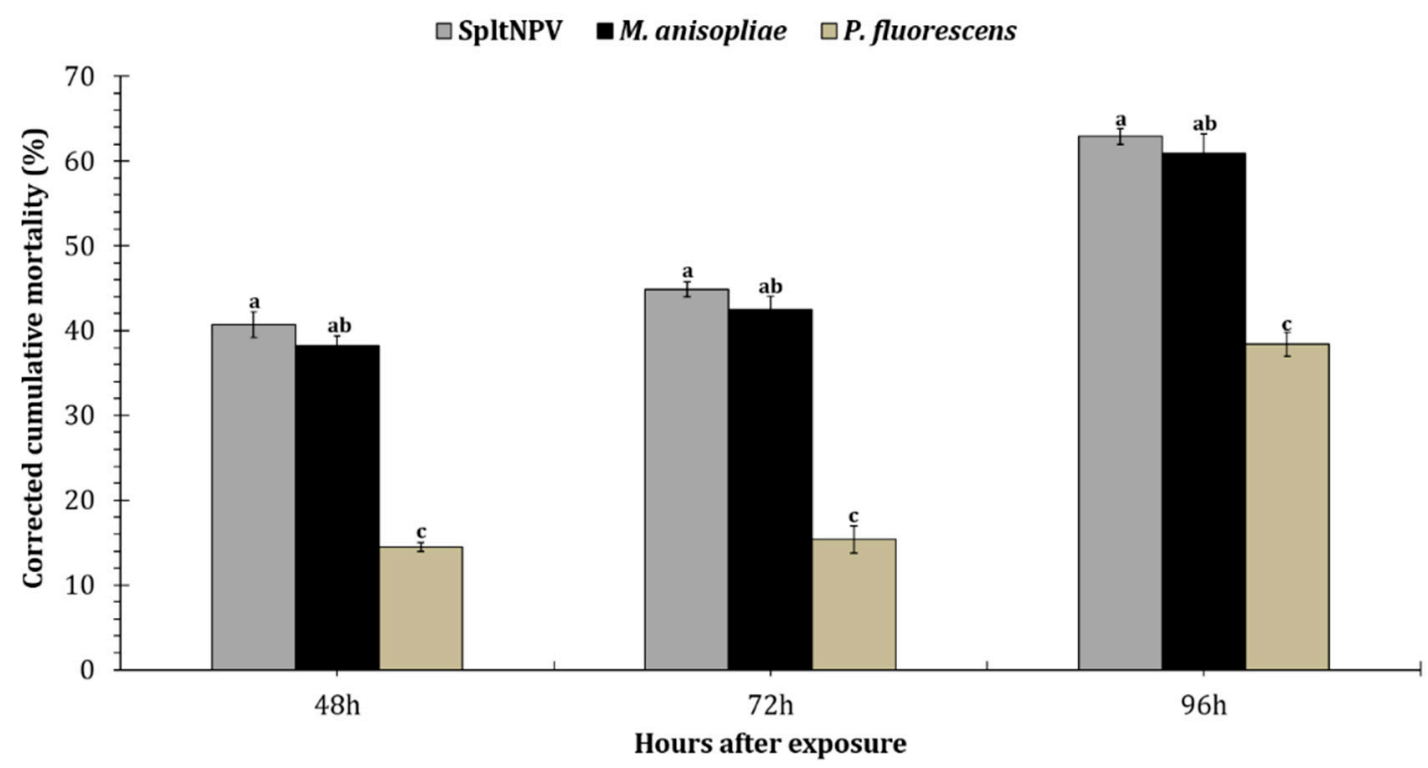

Figure 2. Effect of Spodoptera litura nucleopolyhedrovirus (SpltNPV), Metarhizium anisopliae, and Pseudomonas fluorescens microbe-treated cotton leaf disks on the larval mortality of Spodoptera litura 48, 72 , and $96 \mathrm{~h}$ post-exposure. All values are represented as means \pm SEM. Letters above the mean bars per treatment/exposure time that are different are significantly different (Tukey's test; $p<0.05$ ).

\subsection{Predation Behavior and Bioefficacy of R. kumarii}

During predation, R. kumarii demonstrated the general sequential pattern of: arousal, approach, capturing, paralyzing, and sucking, followed by post-predatory behavior. In the predation analysis, paralyzing and sucking acts were combined as handling time. The predatory behavior, total number of prey, and amount of food consumed by the fourth and fifth nymphal instar and adults of R. kumarii on SpltNPV-, M. anisopliae-, and P. fluorescens-infected S. litura prey are presented in Table 2.

Handling time of the R. kumarii fourth instar was longer when fed prey treated with $M$. anisopliae at $72 \mathrm{~h}(F=4.41 ; \mathrm{df}=1,18 ; p<0.05)$ and $96 \mathrm{~h}(F=4.45 ; \mathrm{df}=1,17 ; p<0.05)$, compared to prey infected with the other treatments and the untreated control. (Table 2). Similar observations as above for the R. kumarii fourth instar were also recorded for the fifth instar [SpltNPV at 24, 48, 72, and $96 \mathrm{~h}(F=4.40$; $\mathrm{df}=1,18 ; p<0.005) ;$ P. fluorescens at $48 \mathrm{~h}(F=4.41 ; \mathrm{df}=1,18 ; p<0.05) ;$ M. anisopliae at $72 \mathrm{~h}(F=4.35$, $\mathrm{df}=1,20 ; p<0.05)]$ and adult $[M$. anisopliae at $24 \mathrm{~h}(F=4.35 ; \mathrm{df}=1,20 ; p<0.05)$ and $72 \mathrm{~h}(F=4.49$; $\mathrm{df}=1,16 ; p<0.005)$; SpltNPV for 24, 48, and $96 \mathrm{~h}(F=4.35 ; \mathrm{df}=1,20 ; p<0.005)$; and P. fluorescens at $48 \mathrm{~h}(F=4.49 ; \mathrm{df}=1,16 ; p<0.005)$ and $96 \mathrm{~h}(F=4.45 ; \mathrm{df}=1,17 ; p<0.05)]$ predators preying on S. litura (Table 2).

In general, there was not much difference observed among the life stages of R. kumarii. A two-way ANOVA was conducted for the mean values data of HT and PR in relation to the fourth and fifth nymphal instars and adult predators. Analyses revealed significant differences for $24 \mathrm{~h}(F=95.53$; $\mathrm{df}=1,2 ; p<0.0001), 48 \mathrm{~h}(F=76.55 ; \mathrm{df}=1,2 ; p<0.0001), 72 \mathrm{~h}(F=281.34 ; \mathrm{df}=1,2 ; p<0.0001)$, and $96 \mathrm{~h}(F=378.38, \mathrm{df}=1,2 ; p<0.0001)$ observations. Furthermore, the overall correlation between the handling time and predatory rate was not significant $\left(R^{2}=0.289,0.2758,0.396\right.$ for fourth and fifth nymphal instars and adult predators, respectively). 
Table 2. Effect of Metarhizium anisopliae-, Spodoptera litura nucleopolyhedrovirus (SpltNPV)-, and Pseudomonas fluorescens-infected Spodoptera litura larvae on the handling time (HT: number of minutes) and predatory rate (PR: number of prey/predator/day) of R. kumarii life stages at 24, 48, 72, and $96 \mathrm{~h}$, compared to the untreated control.

\begin{tabular}{cccccccc}
\hline \multirow{2}{*}{$\begin{array}{c}\text { Exposure } \\
\text { Period (h) }\end{array}$} & Treatments & \multicolumn{2}{c}{ R. kumarii Fourth Instar } & \multicolumn{2}{c}{ R. kumarii Fifth Instar } & \multicolumn{2}{c}{ R. kumarii Adult } \\
\cline { 2 - 7 } & & HT & PR & HT & PR & HT & PR \\
\hline \multirow{4}{*}{24} & Control & $170.8 \mathrm{a}$ & 1.2 & $82.0 \mathrm{~b}$ & 1.0 & $61.8 \mathrm{c}$ & 1.0 \\
& SpltNPV & $75.2 \mathrm{c}$ & 1.2 & $109.8 \mathrm{a}$ & 1.4 & $116.0 \mathrm{a}$ & 1.0 \\
& M. anisopliae & $79.3 \mathrm{c}$ & 1.2 & $71.4 \mathrm{c}$ & 1.4 & $94.6 \mathrm{~b}$ & 1.0 \\
& P. fluorescens & $113.6 \mathrm{~b}$ & 1.9 & $61.4 \mathrm{~d}$ & 1.4 & $63.2 \mathrm{c}$ & 1.0 \\
\hline \multirow{4}{*}{48} & Control & $177.6 \mathrm{a}$ & 1.4 & $141.9 \mathrm{c}$ & 1.0 & $131.6 \mathrm{c}$ & 1.2 \\
& SpltNPV & $163.4 \mathrm{~b}$ & 1.0 & $188.2 \mathrm{~b}$ & 2.2 & $208.6 \mathrm{a}$ & 1.2 \\
& M. anisopliae & $94.8 \mathrm{c}$ & 1.2 & $104.2 \mathrm{~d}$ & 1.4 & $78.4 \mathrm{~d}$ & 1.2 \\
& P. fluorescens & $57.8 \mathrm{~d}$ & 1.2 & $228.5 \mathrm{a}$ & 2.8 & $207.8 \mathrm{ab}$ & 1.9 \\
\hline \multirow{3}{*}{72} & Control & $188.6 \mathrm{c}$ & 1.0 & $166.6 \mathrm{c}$ & 1.2 & $120.8 \mathrm{~b}$ & 1.2 \\
& SpltNPV & $134.3 \mathrm{~d}$ & 1.2 & $172.4 \mathrm{~b}$ & 1.4 & $115.2 \mathrm{bc}$ & 1.6 \\
& M. anisopliae & $219.4 \mathrm{a}$ & 1.4 & $196.8 \mathrm{a}$ & 1.8 & $142.2 \mathrm{a}$ & 1.4 \\
& P. fluorescens & $215.2 \mathrm{~b}$ & 1.4 & $113.2 \mathrm{~d}$ & 1.6 & $98.7 \mathrm{~d}$ & 1.2 \\
\hline \multirow{3}{*}{96} & Control & $169.8 \mathrm{~d}$ & 1.4 & $154.8 \mathrm{~b}$ & 1.6 & $166.6 \mathrm{c}$ & 2.0 \\
& SpltNPV & $199.2 \mathrm{a}$ & 1.0 & $176.2 \mathrm{a}$ & 1.6 & $229.5 \mathrm{a}$ & 2.9 \\
& M. anisopliae & $189.3 \mathrm{~b}$ & 1.4 & $146.6 \mathrm{c}$ & 1.6 & $130.5 \mathrm{~d}$ & 1.6 \\
& P. fluorescens & $177.2 \mathrm{c}$ & 1.6 & $125.4 \mathrm{~d}$ & 1.6 & $221.8 \mathrm{~b}$ & 2.9 \\
\hline
\end{tabular}

Mean values followed by different letters in a column per exposure period are significantly different (Tukey's test, $p<0.05$ ).

The amount of food consumed (mg) by the fourth and fifth nymphal instars and adults of R. kumarii on SpltNPV-, M. anisopliae-, and P. fluorescens-infected S. litura larvae are presented in Table 3.

Table 3. Effect of entomopathogenic microbe-treated and untreated Spodoptera litura prey on the food consumption (mg) of Rynocoris kumarii different life stages at 24, 48, 72, and $96 \mathrm{~h}$ after starvation.

\begin{tabular}{cccccc}
\hline \multirow{2}{*}{$\begin{array}{c}\text { R. } \text { kumarii } \\
\text { Life Stages }\end{array}$} & Treatments & \multicolumn{3}{c}{ Food Consumption (mg) Hours after Starvation } \\
\cline { 3 - 5 } & & $\mathbf{2 4}$ & $\mathbf{4 8}$ & $\mathbf{7 2}$ & $\mathbf{9 6}$ \\
\hline \multirow{4}{*}{ Fourth instar } & Control & $43.6 \pm 2.7 \mathrm{a}$ & $46.2 \pm 1.0 \mathrm{a}$ & $39.2 \pm 3.4 \mathrm{a}$ & $39.2 \pm 2.0 \mathrm{~b}$ \\
& SpltNPV & $8.2 \pm 0.8 \mathrm{c}$ & $23.2 \pm 0.7 \mathrm{~b}$ & $23.3 \pm 0.6 \mathrm{~d}$ & $38.8 \pm 1.2 \mathrm{bc}$ \\
& M. anisopliae & $14.1 \pm 1.2 \mathrm{~b}$ & $23.8 \pm 2.6 \mathrm{~b}$ & $38.4 \pm 0.6 \mathrm{ab}$ & $23.6 \pm 2.6 \mathrm{~d}$ \\
& P. fluorescens & $5.7 \pm 0.7 \mathrm{~d}$ & $17.2 \pm 1.3 \mathrm{c}$ & $29.2 \pm 1.5 \mathrm{c}$ & $54.2 \pm 0.6 \mathrm{a}$ \\
\hline \multirow{5}{*}{ Fifth instar } & Control & $11.0 \pm 1.6 \mathrm{~d}$ & $15.2 \pm 1.5 \mathrm{~d}$ & $14.7 \pm 1.0 \mathrm{~d}$ & $10.8 \pm 0.7 \mathrm{~d}$ \\
& SpltNPV & $21.3 \pm 1.5 \mathrm{bc}$ & $36.3 \pm 1.8 \mathrm{ab}$ & $22.6 \pm 0.9 \mathrm{~b}$ & $22.2 \pm 0.6 \mathrm{~b}$ \\
& M. anisopliae & $28.6 \pm 2.0 \mathrm{a}$ & $31.6 \pm 0.8 \mathrm{c}$ & $28.3 \pm 2.0 \mathrm{a}$ & $29.8 \pm 2.0 \mathrm{a}$ \\
& P. fluorescens & $22.5 \pm 2.0 \mathrm{~b}$ & $37.3 \pm 0.9 \mathrm{a}$ & $18.5 \pm 0.9 \mathrm{c}$ & $19.6 \pm 1.5 \mathrm{c}$ \\
\hline \multirow{5}{*}{ Adults } & Control & $10.2 \pm 0.5 \mathrm{bc}$ & $14.8 \pm 1.0 \mathrm{c}$ & $21.6 \pm 3.4 \mathrm{bc}$ & $42.0 \pm 0.2 \mathrm{~b}$ \\
& SpltNPV & $7.8 \pm 0.3 \mathrm{~d}$ & $29.2 \pm 1.0 \mathrm{~b}$ & $21.6 \pm 1.0 \mathrm{~b}$ & $53.6 \pm 3.2 \mathrm{a}$ \\
& M. anisopliae & $11.9 \pm 0.6 \mathrm{a}$ & $32.2 \pm 2.1 \mathrm{a}$ & $40.8 \pm 2.7 \mathrm{a}$ & $36.2 \pm 1.5 \mathrm{c}$ \\
& P. fluorescens & $11.6 \pm 1.2 \mathrm{ab}$ & $29.2 \pm 1.6 \mathrm{~b}$ & $20.8 \pm 1.0 \mathrm{bd}$ & $30.8 \pm 1.7 \mathrm{~d}$ \\
\hline
\end{tabular}

Means values $( \pm$ SEM) followed by different letters in a column per life stage are significantly different (Tukey's test, $p<0.05)$.

Fourth instar reduviid predators consumed the least amount of $S$. litura treated with $P$. fluorescens at $24(F=247.0 ; \mathrm{df}=1,18 ; p<0.05)$ and $48 \mathrm{~h}(F=250.7 ; \mathrm{df}=1,18 ; p<0.05)$; however, they consumed more at $96 \mathrm{~h}(F=264.0, \mathrm{df}=1,18 ; p<0.05)$ after starvation compared to the other treatments and control. Rhynocoris kumarii fifth instars consumed more $S$. litura larvae treated with the entomopathogenic microbials at $24 \mathrm{~h}$ compared to control $(F=246.0 ; \mathrm{df}=1,17 ; p<0.05)$, but larvae treated with $M$. anisopliae consumed the most for all time intervals except at $48 \mathrm{~h}$ after starvation compared to the other treatments 
and control. The lowest food consumption was observed in adults with SpltNPV-treated prey at $24 \mathrm{~h}$ $(F=248.8 ; \mathrm{df}=1,17 ; p=0.05)$, SpltNPV- and $P$. fluorescens-treated prey at $48 \mathrm{~h}(F=246.9, \mathrm{df}=1,17$; $p<0.05)$, and P. fluorescens at $72 \mathrm{~h}(F=249.51 ; \mathrm{df}=1,17 ; p<0.05)$ and at $96 \mathrm{~h}(F=250.46, \mathrm{df}=1,17$; $p<0.05)$ after starvation compared to the other treatments. Overall, Rhynocoris kumarii fifth instars consumed more $S$. litura larvae treated with the entomopathogenic microbials compared to control from 24-96 h after starvation.

\subsection{Predator Biology}

Rhynocoris kumarii completed its nymphal development after feeding on all the microbial-treated or untreated prey and reached the adult stage successfully. However, when $P$. fluorescens-infected larvae were fed to the reduviid nymphal stages, the developmental time was significantly delayed $(F=3.89$; $\mathrm{df}=1,200 ; p<0.005$ ) compared those larvae treated with SpltNPV or M. anisopliae (Table 4). A similar delayed effect was also observed for the number of days required for total nymphal development amongst the different treatments compared to the control $(F=251.5 ; \mathrm{df}=1,58 ; p<0.05)$. There were no differences $(p>0.05)$ in the sex ratio of $R$. kumarii that were fed with different microbe-treated larvae compared to the control.

Table 4. Effect of Metarhizium anisopliae-, Spodoptera litura nucleopolyhedrovirus- (SpltNPV), and Pseudomonas fluorescens-treated and untreated Spodoptera litura prey consumed by R. kumarii nymphal stages and the total nymphal developmental period (days), survival rate (\%), and the sex ratio of adult $R$. kumarii.

\begin{tabular}{|c|c|c|c|c|c|c|}
\hline \multirow{2}{*}{ Treatments } & \multicolumn{6}{|c|}{ R. kumarii Life Stages or Category } \\
\hline & Third Instar & Fourth Instar & Male & Female & $\begin{array}{l}\text { Total Nymphal } \\
\text { Development } \\
\text { Period (Days) * }\end{array}$ & $\begin{array}{c}\text { Sex Ratio } \\
\text { (Female:Male) }\end{array}$ \\
\hline Control & $11.3 \pm 0.8 \mathrm{~d}(100)^{*}$ & $11.3 \pm 0.3 \mathrm{~d}(100)$ & $26.0 \pm 0.3 \mathrm{a}(100)$ & $28.0 \pm 0.3 \mathrm{a}(100)$ & $60.0 \pm 1.3 \mathrm{~d}$ & 0.47 \\
\hline SpltNPV & $14.0 \pm 0.7 \mathrm{a}(100)$ & $15.0 \pm 0.5 \mathrm{bc}(80.67)$ & $21.1 \pm 0.2 b(96.77)$ & $25.2 \pm 0.3 b(91.66)$ & $66.9 \pm 2.3 b$ & 0.45 \\
\hline M. anisopliae & $13.0 \pm 0.3 \mathrm{bc}(100)$ & $16.2 \pm 0.8 \mathrm{ab}(100)$ & $16.4 \pm 0.5 \mathrm{~d}(90.23)$ & $19.0 \pm 0.9 \mathrm{~d}(80.89)$ & $64.6 \pm 1.3 c$ & 0.46 \\
\hline P. fluorescens & $13.2 \pm 0.2 b(100)$ & $16.4 \pm 0.2 \mathrm{a}(100)$ & $17.3 \pm 0.6 \mathrm{c}(100)$ & $23.7 \pm 0.7 \mathrm{c}(100)$ & $68.4 \pm 0.9 a$ & 0.52 \\
\hline
\end{tabular}

\section{Discussion}

In the current study, we found that SpltNPV treatment highly deterred S. litura larvae initially, and subsequently reduced the food consumption index, approximate digestibility and absorption capacity, and affected the relative growth rate. When $S$. litura-infected larvae were fed to a generalist predator, it affected their food consumption and nymphal development. Various studies have shown that SpltNPV [19,23], M. anisopliae [25], and P. fluorescens [11] are promising microbial biological control agents of S. litura. When considering field applications of any of these entomopathogenic microbes (EPMs) alone or in combination with other crop protection strategies, including the release of natural enemies such as reduviid predators, it is imperative to understand the potential interactions of these biological control agents and their compatibility with natural enemies. Results from this current study have demonstrated under laboratory conditions that there is potential for integrating the reduviid R. kumarii with other microbial biological control agents, especially the tested EPMs. In the current study, commercial formulations of SpltNPV and P. fluorescens were used, unlike the laboratory-cultured colony of $M$. anisopliae. Thus, the impact of adjuvants present in the commercial products on $S$. litura could not be ruled out. To minimize possible variations in the treatment effect because of any adjuvants, we used Tween 80 with M. anisopliae. However, it is imperative to record the impact of adjuvants on both pest and predators to make a better judgement concerning the treatment selection.

There is scarce literature outlining the multitrophic interaction of EPMs-pest/predator, even though these organisms share the same habitat. Under field conditions, SpltNPV, M. anisopliae, 
and P. fluorescens have been isolated from S. litura larvae $[11,19,23,25]$; however, their impact on reduviid predators was not previously known. This study provides the first assessment of the interaction of three EPMs, a pest, and a reduviid predator, R. kumarii, under laboratory conditions. Results indicated that during the 24,48 , and $72 \mathrm{~h}$ observation period, the commercial SpltNPV formulation highly deterred the feeding activity of S. litura. However, at $96 \mathrm{~h}, M$. anisopliae deterred the feeding activity more than the other two EPMs. Similarly, a strong antifeedant activity of M. anisopliae crude extract against S. littoralis Boisduval larvae was reported earlier by Quesada-Moraga et al. [21]. Furthermore, Hu et al. [9] observed that larvae of S. litura were repelled by M. anisopliae toxins (destruxins, depsipeptides), and their death was presumably due to starvation as opposed to toxicosis. Therefore, we assume that the presence of biochemical compounds of M. anisopliae-infected S. litura larvae in the present study resulted in deterrence and antifeeding activity leading to starvation and death of the larvae.

The Spodoptera-specific virus SpltNPV has been applied to suppress the pest populations in many countries [23,24]. Also, SpltNPV and a Pseudomonas chitinase $\mathrm{C}$ gene $(P s C h i C)$ caused $51.1 \%$ and $17.8 \%$ mortality against second instar larvae of $S$. litura after $196 \mathrm{~h}$, respectively [52]. In contrast, our results revealed higher mortality of S. litura third instar larvae in SpltNPV $(62.9 \%)$ and P. fluorescens $(38.4 \%)$ treatments even at $96 \mathrm{~h}$, which could have occurred due to the differences in the selected age group of the pest population. However, the use of SpltNPV has several potential limitations, and work conducted by Sun [53] and Reynolds et al. [54] stressed the importance of finding new alternative EPMs. Of the EPMs tested, this study is the first to report that $P$. fluorescens is effective in killing the larvae of $S$. litura under laboratory conditions. However, further studies regarding the characteristics of the P. fluorescens metabolites present in the formulation, their modes of action, and efficacy in the field still need to be conducted. Recently, a Pseudomonas sp. (TXG6-1) chitinase C gene (PsChiC) was introduced for the management of S. litura $\left(1 \times 10^{7}\right.$ particles) [52]. In addition to the use of Pseudomonas as an alternative EPM, various strains of M. anisopliae applied at $10^{8}$ conidia $/ \mathrm{mL}$ caused $67 \%$ mortality to S. litura for third instar larvae [52].

Results from this study also indicated that the deterrent activity of SpltNPV reduced the feeding activity of S. litura, and thus reduced the efficiency of consumption of ingested and digested food, reduced weight gain, reduced the production of fecal pellets, and subsequently slowed the relative growth rate and quickly caused mortality. This indicates that the virus altered the entire digestive physiology of the pest; hence, we can suggest that SpltNPV can be used as an alternative potential EPM for pest management of $S$. litura. The negative correlation between food consumption and fecal pellet production might be due to the direct effect of SpltNPV in decreasing the metabolism as well as the rate of transport of metabolites needed for enzyme regulation. Other authors have corroborated our findings and indicated that consumed food was retained in the gut for a long time to meet the increased demand of nutrients by the EPMs multiplying in the host tissue [22,54-56].

Integration of commercial EPMs with other pest management components has been encouraged by many researchers. As a generalist predator, being distributed worldwide and abundant in many agroecosystems, reduviids have also been recommended for pest management programs [30]. In India, R. kumarii is abundant in many agroecosystems and known to be an important predator of many pestiferous insects including S. litura $[18,20,22,25,32]$. Results from this study revealed that the provision of EPM-infected S. litura larvae fed to the reduviid predator R. kumarii did not affect its food consumption. In the presence of EPMs, the predator generally requires more time needed to handle the prey (except fourth instars at 24 and $48 \mathrm{~h}$ and adults at $72 \mathrm{~h}$ ), which is based on an aggregate variable that includes the following behavioral components: identifying, pursuing, capturing, consuming, and digesting the prey. In addition, when the life stages of R. kumarii were fed EPM-infected larvae, the nymphal total stadial period was prolonged by eight days by $P$. fluorescens compared to SpltNPV. However, this prolonged developmental period did not reduce the survival rate of the nymphs and indicated that the EPMs are compatible with the reduviid fitness. Furthermore, no differences in size were observed between the control and experimental predators (Sahayaraj, K.; unpublished 
data). A similar observation was also made for the nabid predator Nabis roseipennis Reuter when fed NPV-infected soybean looper, Pseudoplusia includens Walker, e.g., the infected larvae did not affect their survival rate, but the predator had a longer developmental time period than those fed with healthy prey [57]. Furthermore, studies are still warranted and necessary to understand the exact mechanism involved in the survival of the reduviid after consuming EPM-infected prey.

Prey quality is important in determining the fitness of any natural enemy, including reduviid predators. Infection by EPMs may alter the chemical cues or nutritional content of $S$. litura larvae, which in turn may affect the reduviid predator performance and biological control efficacy. Previously, it was reported that NPV had a detrimental effect on the development of reduviids such as R. marginatus [47], S. leucomesus [44], and another generalist predator, Eocanthecona furcellata Wolffin [58], that all feed on S. litura larvae. However, later authors also reported impaired development in S. leucomesus, but not in R. kumarii, which demonstrates the resistance capacity of this reduviid to bacteria and viruses. During this study, we never observed microbial infectivity in any field-collected reduviids from any of the agroecosystems.

\section{Conclusions}

The entomopathogenic microbes SpltNPV, M. anisopliae, and P. fluorescens altered the feeding behavior and subsequent food consumption and weight gain, fecal pellet production, and relative growth rate of $S$. litura. This effect was most pronounced with M. anisopliae, followed by SpltNPV and then P. fluorescens during the four-day observation period. Our findings confirm the prospects for the development of more competitive P. fluorescens bioinsecticides for S. litura. Results indicate that all three entomopathogens could potentially be integrated with the R. kumarii predator in an integrated pest management program for the biological control of $S$. litura in cotton agroecosystems.

Author Contributions: Conceptualization, K.S. and N.S.; Data curation, L.K.M.; Formal analysis, K.S. and N.S.; Investigation, N.S.; Methodology, K.S.; Project administration, K.S.; Resources, R.W.A., V.K., P.B.A., L.K.M., C.L.M., and L.S.O.; Validation, P.B.A. and L.K.M.; Visualization, R.W.A. and V.K.; Writing-review \& editing, R.W.A., V.K., P.B.A., C.L.M. and L.S.O.

Acknowledgments: We are grateful to Rev. A. Antonysamy, S.J., and Rev. Britto Vincent, S.J., authorities of St. Xavier's College, Palayamkottai, for providing the necessary laboratory facilities.

Conflicts of Interest: The authors declare no conflict of interest.

\section{References}

1. Noma, T.; Colunga-Garcia, M.; Brewer, M.; Landis, J.; Gooch, A. Oriental leafworm, Spodoptera litura. Michigan State University's invasive species fact sheets. Feburary 2010. Available online: www.canr.msu. edu/ipm/uploads/files/Forecasting_invasion_risks/orientalLeafworm.pdf (accessed on 18 July 2018).

2. Punithavalli, M.; Sharma, A.N.; Balaji, RM. Seasonality of the common cutworm Spodoptera litura in a soybean ecosystem. Phytoparasitica 2014, 42, 213-222. [CrossRef]

3. Rao, M.S.; Manimanjari, D.; Rao, A.C.R.; Swathi, P.; Maheswari, M. Effect of climate change on Spodoptera litura Fab. on peanut: A life table approach. Crop Prot. 2014, 66, 98-106.

4. Kranthi, K.R.; Jadhav, D.R.; Kranthi, S.; Wanjari, R.R.; Ali, R.R.; Russell, D.A. Insecticide resistance in five major insect pests of cotton in India. Crop Prot. 2002, 21, 449-460. [CrossRef]

5. Gandhi, K.; Patil, R.H.; Srujana, Y. Field resistance of Spodoptera litura (Fab.) to conventional insecticides in India. Crop Prot. 2016, 88, 103-108.

6. Abbas, N.; Shad, A.A.; Razaq, M. Fitness cost, cross resistance and realized heritability of resistance to imidacloprid in Spodoptera litura (Lepidoptera: Noctuidae). Pest. Biochem. Physiol. 2012, 103, 181-188. [CrossRef]

7. Shad, S.; Sayyed, A.; Fazal, S.; Saleem, M.; Zaka, S.; Ali, M. Field evolved resistance to carbamates, organophosphates, pyrethroids, and new chemistry insecticides in Spodoptera litura Fab. (Lepidoptera: Noctuidae). J. Pest. Sci. 2012, 85, 153-162. [CrossRef] 
8. Yang, M.M.; Meng, L.L.; Yongan, Z.; Yu, Z.W.; Liang, J.Q.; Qing, H.W.; Jin, Y.D. Baculoviruses and insect pests control in China. Afr. J. Microbiol. Res. 2012, 6, 214-218. [CrossRef]

9. Radja Commare, C.; Nandakumar, R.; Kandan, A.; Suresh, S.; Bharathi, M.; Raguchander, T.; Samiyappan, R. Pseudomonas fluorescens based bio-formulation for the management of sheath blight disease and leaf folder insect in rice. Crop Prot. 2002, 21, 671-677. [CrossRef]

10. Hu, Q.B.; Ren, S.X.; An, X.C.; Qian, M.H. Insecticidal activity influence of destruxins on the pathogenicity of Paecilomyces javanicus against Spodoptera litura. J. Appl. Entomol. 2007, 131, 262-268. [CrossRef]

11. Bhanu Prakash, G.V.; Padmaja, V.; Jami, S.K.; Kirti, P.B. Expression of chitinase genes of Metarhizium anisopliae isolates in lepidopteran pests and on synthetic media. J. Basic Microbiol. 2012, 52, 628-635. [CrossRef] [PubMed]

12. Mohana, S.A.; Dhandapani, N.; Shiv Sankar, H.D.; Muthukumar, P. Effect of gibberellic acid $\left(\mathrm{GA}^{3}\right)$ and Pseudomonas fluorescens (migula) on the ovipositional behaviour of Plutella xylostella (L.) and Spodoptera litura (Fab.). Bull. Agric. Sci. 2006, 4, 55-58.

13. Pechy-Tarr, M.; Bruck, D.J.; Maurhofer, M.; Fischer, E.; Vogne, C.; Henkels, M.D.; Donahue, K.M.; Grunder, J.; Loper, J.E.; Keel, C. Molecular analysis of a novel gene cluster encoding an insect toxin in plant-associated strains of Pseudomonas fluorescens. Environ. Microbiol. 2008, 10, 2368-2386.

14. Mohana, S.A.; Dhandapani, N. Gibberellic acid $\left(\mathrm{GA}^{3}\right)$ and Pseudomonas fluorescens as components of biointensive pest management strategy against Plutella xylostella in cauliflower. Pest Manag. Hort. Ecosyst. 2009, 15, 1-8.

15. Kumari, V.; Singh, N.P. Spodoptera litura nuclear polyhedrosis virus (NPV-S) as a component in integrated pest management (IPM) of Spodoptera litura (Fab.) on cabbage. J. Biopest. 2009, 2, 84-86.

16. Nakai, M.; Nguyen, T.T.C. Field application of an insect virus in the Mekong Delta: Effects of a Vietnamese nucleopolyhedrovirus on Spodoptera litura (Lepidoptera: Noctuidae) and its parasitic natural enemies. Biocontrol Sci. Technol. 2005, 15, 443-453. [CrossRef]

17. Singha, D.; Singha, B.; Dutta, B.K. Potential of Metarhizium anisopliae and Beauveria bassiana in the control of tea termite Microtermes obesi Holmgren in vitro and under field conditions. J. Pest Sci. 2011, 84, 69-75. [CrossRef]

18. Fadare, T.A.; Amusa, N.A. Comparative efficacy of microbial and chosen insecticides on four major lepidopterous pests of cotton and their natural enemies. African J. Biotechnol. 2003, 2, 425-428.

19. Gupta, R.K.; Amin, M.; Bali, K.; Monobrullah, M.; Jasrotia, P. Vertical transmission of sublethal granulovirus infection in the tobacco caterpillar Spodoptera litura. Phytoparasitica 2010, 38, 209-216. [CrossRef]

20. Sahayaraj, K.; Borgio, J.F. Virulence evaluation of entomopathogenic fungus Metarhizium anisopliae (Metsch.) Sorokin (Hyphomycetes) on seven insect pests. Indian J. Agric. Sci. 2010, 44, 195-200.

21. Quesada-Moraga, E.; Carrasco-Díaz, J.A.; Santiago-Álvarez, C. Insecticidal and antifeedant activities of proteins secreted by entomopathogenic fungi against Spodoptera littoralis (Lepidoptera: Noctuiidae). J. Appl. Entomol. 2006, 130, 442-452. [CrossRef]

22. Shapiro, M.; Robertson, J.L.; Webb, R.E. Effect of neem seed extract upon the gypsy moth (Lepidoptera: Lymantriidae) and its nuclear polyhedrosis virus. J. Econ. Entomol. 1994, 87, 356-360. [CrossRef]

23. Jun, T.; Shohei, O.; Takayoshi, I.; Madoka, N.; Yasuhisa, K. Productivity and quality of polyhedral occlusion bodies of a nucleopolyhedrovirus harvested from Spodoptera litura (Lepidoptera: Noctuidae) larvae. Appl. Entomol. Zool. 2007, 42, 21-26.

24. Rao, G.V.R.; Kumar, C.S.; Sireesha, K.; Kumar, P.L. Role of nucleopolyhedroviruses (NPVs) in the management of lepidopteran pests in Asia. In Biocontrol of Lepidopteran Pests, Soil Biology; Sree, K.S., Varma, A., Eds.; Springer International Publishing: Berlin, Germany, 2015; pp. 11-52.

25. Petlamul, W.; Prasertsan, P. Evaluation of strains of Metarhizium anisopliae and Beauveria bassiana against Spodoptera litura on the basis of their virulence, germination rate, conidia production, radial growth and enzyme activity. Mycobiology 2012, 40, 111-116. [CrossRef] [PubMed]

26. Sowjanya Sree, K.; Padmaja, V.; Murthy, Y.L. Insecticidal activity of destruxin, a mycotoxin from Metarhizium anisopliae (Hypocreales), against Spodoptera litura (Lepidoptera: Noctuidae) larval stages. Pest Manag. Sci. 2008, 64, 119-125. [CrossRef] [PubMed]

27. Ramamoorthy, V.; Viswanathan, R.; Raguchander, T.; Prakasam, V.; Samiyappan, R. Induction of systemic resistance by plant growth promoting rhizobacteria in crop plants against pest and diseases. Crop Prot. 2001, 20, 1-11. [CrossRef] 
28. Roobakkumar, A.; Babu, A.; Vasantha Kumar, D.; Rahman, V.K.; Sarkar, S. Pseudomonas fluorescens as an efficient entomopathogen against Oligonychus coffeae Nietner (Acari: Tetranychidae) infesting tea. J. Entomol. Nematol. 2011, 3, 73-77.

29. Al-Sohim, A.S.; Fouly, A.F. Biological effects of two bacterial isolates and mutants of Pseudomonas fluorescens on date palm red spider mite, Oligonychus afrasiaticus (Acari: Tertanychidae). Egyptian J. Biol. Pest Control 2015, 25, 513-518.

30. Sahayaraj, K. Reduviids and their merits in biological control. In Basic and Applied Aspects of Biopesticides; Springer: New Delhi, India, 2014; pp. 195-214.

31. Ambrose, D.P. Assassin Bugs; USA Science Publishers Inc.: Enfield, NH, USA, 1999; p. 337.

32. Grundy, P.; Maelzer, D. Assessment of Pristhesancus plagipennis (Walker) (Hemiptera: Reduviidae) as an augmented biological control in cotton and soybean crops. Aust. J. Entomol. 2000, 39, 305-309. [CrossRef]

33. Sahayaraj, K. Pest Control Mechanism of Reduviids; ABD Publisher: Jaipur, India, 2007; p. 240.

34. Sahayaraj, K. Hunter reduviidae in pest management for plantation crops. Proceeding of National Seminar on Harmful/Beneficial Insects of Agricultural Importance, Calicut, India, 17-18 February 2011; pp. 42-51.

35. Sahayaraj, K.; Kalidas, S.; Majesh, T. Stage preference and functional response of Rhynocoris longifrons (Stål) (Hemiptera: Reduviidae) on three hemipteran cotton pests. Braz. Arch. Biol. Technol. 2012, 55, 733-740. [CrossRef]

36. Sahayaraj, K.; Asha, A. Biological control potential evaluation of Rhynocoris kumarii Ambrose and Livingstone (Hemiptera: Reduviidae) on Aphis craccivora (Koch.) (Hemiptera: Aphididae). Indian J. Agric. Res. 2010, 44, 281-287.

37. Claver, M.A.; Ambrose, D.P. Evaluation of Rhynocoris kumarii Ambrose \& Livingstone (Hemiptera: Reduviidae) as a potential predator of some lepidopteran pests of cotton. J. Biol. Control 2001, 15, 15-20.

38. Ambrose, D.P. Suppression of Helicoverpa armigera (Hubner) and Anomis flava (Fab.) infesting okra by the reduviid predator Rhynocoris kumarii Ambrose and Livingstone in field cages. Pest Manag. Hort. Ecosyst. 2000, 6, 32-35.

39. Claver, M.A.; Ambrose, D.P. Impact of augmentative release of Rhynocoris kumarii Ambrose \& Livingstone (Heteroptera: Reduviidae) on Dysdercus cingulatus (Fabricius) (Hemiptera: Pyrrhocoridae) population and damage on cotton. J. Biol. Control 2001, 15, 119-125.

40. Claver, M.A.; Kalyanasundaram, M.; David, P.M.M.; Ambrose, D.P. Abundance of boll worm, flower beetle, predators and field colonization by Rhynocoris kumarii (Heteroptera: Reduvidae) following mulching and shelter provisioning in cotton. J. Appl. Entomol. 2003, 127, 383-388. [CrossRef]

41. Sahayaraj, K.; Ravi, C. Evaluation of reduviid predators and plant products against chosen groundnut pests. Arch. Phytopathol. Plant Prot. 2007, 40, 281-290. [CrossRef]

42. Cooper, D.J. The role of predatory hemiptera in disseminating a nuclear polyhedrosis virus of Heliothis punctiger. Aust. J. Entomol. 1981, 20, 145-150. [CrossRef]

43. Thungrabeab, M.; Tongma, S. Effect of entomopathogenic fungi, Beauveria bassiana (Balsam) and Metarhizium anisopliae (Metsch.) on non target insects. KMITL Sci. Technol. J. 2007, 7, 8-12.

44. Sajap, A.S.; Kotuli, J.R.; Kadir, H.A.; Hussein, M.Y. Impact of prey infected by nuclear polyhedrosis virus on a predator, Sycanus leucomesus Walk. (Hemiptera: Reduviidae). J. Appl. Entomol. 1999, 123, 93-97. [CrossRef]

45. Abbas, M.S.T.; Boucias, D.G. Interaction between nuclear polyhedrosis virus-infected Anticarsia gemmatalis (Lepidoptera: Noctuidae) larvae and a predator Podisus maculiventris (Say) (Hemiptera: Pentatomidae). Environ. Entomol. 1984, 13, 599-602. [CrossRef]

46. George, P.J.E.; Ambrose, D.P. Insecticidal impact on the post-embryonic development of Rhynocoris kumarii Ambrose and Livingstone (Heteroptera: Reduviidae). J. Appl. Entomol. 1999, 123, 509-512. [CrossRef]

47. Sahayaraj, K.; Karthikraja, S. Effect of biopesticides on Rhynocoris marginatus (Fab.) (Heteroptera: Reduvidae). J. Biol. Control 2003, 17, 43-45.

48. Sahayaraj, K.; Abitha, J.M.; Selvaraj, P. Side effects of selected biopesticides on reduviid predator Rhynocoris marginatus Fab. Entomol. Croat. 2003, 7, 43-50.

49. Sahayaraj, K.; Lalitha, C.; Balasubramaniam, R. Biosafety of Metarhizium anisopliae (Metschnikoff) Sorokin on a reduviid predator Acanthaspis pedestris (Hemiptera: Reduviidae). Hexapoda 2008, 15, 46-48.

50. Isman, M.B.; Koul, O.; Luczynski, A.; Kaminski, J. Insecticidal and antifeedant bioactivities of neem oils and their relationship to azadirachtin content. J. Agric. Food Chem. 1990, 38, 1406-1411. [CrossRef]

51. Waldbauer, G.P. The consumption and utilization of food by insects. Adv. Insect Physiol. 1968, 5, $229-287$. 
52. Zhong, W.; Ding, S.; Guo, H. The chitinase C gene PsChiC from Pseudomonas sp. and its synergistic effects on larvicidal activity. Gen. Mol. Biol. 2015, 38, 366-372. [CrossRef] [PubMed]

53. Sun, X. History and current status of development and use of viral insecticides in China. Viruses 2015, 7, 306-319. [CrossRef] [PubMed]

54. Reynolds, S.E.; Nottingham, S.F.; Stephens, A.E. Food and water economy and its relation to growth in fifth-instar larvae of tobacco hornworm, Manduca sexta. J. Insect Physiol. 1985, 31, 119-127. [CrossRef]

55. Inceoglu, A.B.; Kamita, S.G.; Hammock, B.D. Genetically modified baculoviruses: A historical overview and future outlook. Adv. Virus Res. 2006, 68, 323-360. [PubMed]

56. Rath, S.S.; Prasad, B.C.; Sinha, B.R. Food utilization efficiency in fifth instar larvae of Antheraea mylitta (Lepidoptera: Saturniidae) infected with Nosema sp. and its effect on reproductive potential and silk production. J. Invertebr. Pathol. 2003, 83, 1-9. [CrossRef]

57. Ruberson, J.R.; Young, S.Y.; Kring, T.J. Suitability of prey infected by nuclear polyhedrosis virus for development, survival, and reproduction of the predator Nabis roseipennis (Heteroptera: Nabidae). Environ. Entomol. 1991, 20, 1475-1479. [CrossRef]

58. Gupta, R.K.; Gani, M.; Jasrotia, P.; Srivastava, K. Development of the predator Eocanthecona furcellata on different proportions of nucleopolyhedrovirus infected Spodoptera litura larvae and potential for predator dissemination of virus in the field. BioControl 2013, 58, 543-552. [CrossRef]

(C) 2018 by the authors. Licensee MDPI, Basel, Switzerland. This article is an open access article distributed under the terms and conditions of the Creative Commons Attribution (CC BY) license (http:/ / creativecommons.org/licenses/by/4.0/). 